\title{
Diversity of microfungi in ornithogenic soils from Beaufort Island, continental Antarctic
}

\author{
Siti Aisyah Alias ${ }^{1 *}$, Jerzy Smykla ${ }^{2}$, Chin Yoon Ming ${ }^{1}$, Mohammed \\ Rizman-Idid ${ }^{1,3}$, Peter Convey ${ }^{1,4}$
}

${ }^{I}$ National Antarctic Research Centre (NARC), B303, Block B, Level 3, IGS Building, University of Malaya, 50603 Kuala Lumpur, Malaysia

${ }^{2}$ Department of Biodiversity, Institute of Nature Conservation, Polish Academy of Sciences, Mickiewicza 33, PL-31-120 Krakow, Poland

${ }^{3}$ Institute of Ocean and Earth Sciences, C308, IGS Building, University of Malaya, 50603 Kuala Lumpur, Malaysia

${ }_{1,4}^{1,4}$ British Antarctic Survey, High Cross, Madingley Road, Cambridge CB3 OET, United Kingdom

\begin{abstract}
This paper presents the results of a biodiversity study of microfungi in ornithogenic soils from Beaufort Island (Ross Sea, continental Antarctic). During the 2004/05 austral summer, we sampled a wide range of soil habitats from an abandoned penguin rookeries to examine the biodiversity of soil microfungi. Beaufort Island is predominantly ice and snow covered, isolated, difficult to access and known to have been visited only infrequently. Warcup's soil plating method was used for fungal cultivation. A total of ten fungal taxa were isolated, consisting of seven ascomycetes, two anamorphic fungi and one yeast. In terms of their thermal classes, a total of four psychrophilic, five psychrotolerant and 1 mesophilic fungi were isolated. Thelebolus microsporus, Geomyces sp. and Thelebolus sp. were the most common isolated fungi. Internal Transcribed Spacer (ITS) and 18S rDNA sequences were obtained from 17 fungal isolates, confirming their identification as Thelebolus microsporus, Thelebolus sp., Phoma herbarum and Geomyces sp.
\end{abstract}

Key words: Antarctica, soil fungi, biodiversity, ornithogenic

DOI: $10.5817 / \mathrm{CPR} 2013-2-15$

Received November 9, 2013, accepted December 12, 2013.

*Corresponding author: Siti Aisyah Alias<saa@um.edu.my>

Acknowledgements: The authors thank Steven Emslie, Larry Coats and personnel of the US Station McMurdo for logistical aid and comradeship during the field studies. The field survey was made possible by the logistical support from the US NSF Antarctic Program within grant no. ANT 0739575 to Steven Emslie. This work was also supported by the Ministry of Science, Technology and Innovation of Malaysia (MOSTI) within grant no. 8123206 and the Polish Ministry of Science and Higher Education within the program 'Supporting International Mobility of Scientists' and grants nos. 2P04F00127 and NN305376438. Peter Convey is supported by Natural Environment Research Council core funding to the British Antarctic Survey's 'Ecosystems' research programme, and by a University of Malaya Visiting Professorship. The paper contributes to the Scientific Committee on Antarctic Research (SCAR) program: Evolution and Biodiversity in the Antarctic (EBA). 


\section{Introduction}

\section{Antarctic microfungal diversity}

Studies of microfungal diversity in Antarctic have generally focused on the continental (Sugiyama et al. 1967, Wicklow 1968, Atlas et al. 1978, Friedmann 1982, Martin 1988, Del Frate et Carretta 1990, Onofri et Tosi 1992, Moller et Gams 1993, Smith 1994, Azmi et Seppelt 1998, Cheryl et Seppelt 1999, Selbmann et al. 2005, Krishnan et al. 2011) rather than the maritime Antarctic (Dennis 1968, Gray et al. 1982, Pugh et Allsopp 1982, Weinstein et al. 1997). Studies have taken place both in relatively easily accessible and more benign locations (Azmi et Seppelt 1990, Cheryl et Seppelt 1999) and in more environmentally challenging areas such as the Victoria Land Dry Valleys (Friedmann et al. 1985, Cameron et al. 1971). The occurrence of fungi associated with humanassociated habitats and artifacts, such as in historical huts, have been studied extensively by Tubaki (1961), Martin (1988), Blanchette (2000), Blanchette et al. (2004) and Held et al. (2005).

The indigenous fungi of Antarctica have been studied in soils (Kerry 1990a, b, Finotti 1993, Azmi et Seppelt 1998, Hughes et al. 2003, Krishnan et al. 2011), ice cores and permafrost (Gilichinsky et al. 2005), lake sediment (Sugiyama et al. 1967) and also in the air column (Marshall 1997). Airborne spores originating from South America have also been detected in the
Antarctic Peninsula region (Marshall 1997). Sugiyama et al. (1967) reported Aspergillus spp. and Penicillium sp. as the only identifiable fungi from water, sediments and soils of Lake Vanda, with more isolates being recorded from sediments compared to water and soil samples. They also detected greater diversity of fungi in culture at $25^{\circ} \mathrm{C}$ compared to $10^{\circ} \mathrm{C}$. Gilichinsky et al. (2005) isolated 40 fungal strains representing 12 different taxa from cryopegs of Don Juan Pond, including Geomyces sp., Penicillium spp., Alternaria sp., Aureobasidium sp. and Verticillium spp., again noting very little growth at $10^{\circ} \mathrm{C}$. Tubaki (1968) highlighted that the ability to continue slow growth at low temperature (i.e. near $0^{\circ} \mathrm{C}$ ) might be more ecologically relevant than rapid growth rates at higher optimum culture temperatures.

The relationship between vertebrate presence and microfungal diversity in Antarctica has been reported by Wicklow (1968), Kerry (1990a, b) and Azmi et Seppelt (1998). Thelebolus spp. and Phoma sp. have been recorded in such vertebrate associated soils, for example, from the Windmill Islands (Azmi et Seppelt 1998, Cheryl et Seppelt 1999, Alias et al. 2005), Vestfold Hills and MacRobertson Island (Kerry 1990a).

\section{Seabird influence on Antarctic terrestrial ecosystems}

Antarctica's terrestrial ecosystems are fragile and easily affected by human or animal activities (Chown et Gaston 2000, Selmi et Boulinier 2001, Frenot et al. 2005). Seabirds and marine mammals, such as penguins and seals, feed in the surrounding ocean and reproduce and rest on land. There, they deposit large quantities of excrement (guano) and other organic material such as feathers, eggs and carcasses, hence fertilizing the otherwise nutrient-poor terrestrial ecosystem (Allen et al. 1967, Smith 1985, Myrcha et al. 1985, Myrcha et Tatur 1991, Tatur 2002, Zmudczyńska et al. 2012). For instance, Tatur (2002) reported that the $30-50,000$ 
pairs of Pygoscelis penguins nesting on the west shore of Admiralty Bay, King George Island, maritime Antarctic deposited about 6.35 tonnes of guano (dry mass equivalent) on the land daily. The runoff from penguin rookeries will fertilize the immediate surrounding area (Park et al. 2007), while strong winds will transport and redistribute fine particles of guano and volatilized ammonia to a wider area (Wodehouse et Parker 1981). The vegetation zonation around areas of vertebrate concentration can be very distinct (Smykla et al. 2007), and indicative of the degree of rookery impact.

Soil chemistry is also impacted by the vertebrate presence. Potassium and marinederived salts have been detected (Rankin et Wolff 2000). Soils near penguin rooker-

\section{Beaufort Island}

Beaufort Island, located in the Ross Sea, is mostly ice- or snow-covered, but includes a variety of ice-free terrains and habitats that support relatively diverse biota (Seppelt et al. 1999). The island is isolated, difficult to access, and is known to have been visited only infrequently. The earliest scientific report is that of Stonehouse (1966). Further ornithological studies were reported by Woehler (1993) and Woehler et Croxall (1996). The natural biota and ecosystem of Beaufort Island therefore provide an ideal reference for such systems in the Ross Sea region.

The island includes several relictual penguin rookeries, and areas are dominated by matted layers of pin feathers that are characteristic of molting sites (Seppelt ies were also found to contain high concentrations of low molecular weight sugars and polyols (in the form of monoand disaccharides) in areas characterized by visible algal growth (Roser et al. 1994). Within the occupied penguin rookeries soils can contain high levels of organic acids such as oxalic, acetic, propionic and succinic acids (Roser et al. 1994). The surface layer of soils of active penguin rookeries contains fresh and leached guano underlain by aluminium-iron phosphatic clay (Tatur et al. 1997). It is generally entirely devoid of vegetation because of toxic overmanuring and active trampling. In contrast, abandoned penguin rookery sites can progressively become covered by extensive vegetation (Smykla et al. 2007).

et al. 1996, Emslie et al. 2007). The oldest known records for the Adélie penguin have been identified from here (Emslie et al. 2007), with the ages of some feathers and bones exceeding the range of radiocarbon dating (more than 44,000 years old).

In the absence of previous studies of the mycobiota of Beaufort Island our objectives were to isolate, obtain axenic cultures and identify microfungi from soils on the island, in particular focusing on the soils of relict areas of penguin activity. We include molecular phylogenetic analyses of the microfungi isolated using the Internal Transcribed Spacer (ITS) and 18S rDNA sequences. 


\section{Materials and Methods}

\section{Sampling Site - Beaufort Island}

The study area was located in the northern part of Beaufort Island ( $76^{\circ} 57^{\prime} \mathrm{S}$, $\left.166^{\circ} 55^{\prime} \mathrm{E}\right)$. This site has a northerly aspect and is sheltered from the cold southerly winds, therefore experiencing relatively warm summer temperatures (see Fig. 1). The local microclimate, stability of substratum and supply of water from the nearby ice cliffs and snow fields provide conditions favourable for supporting a relatively diverse terrestrial biota. This site

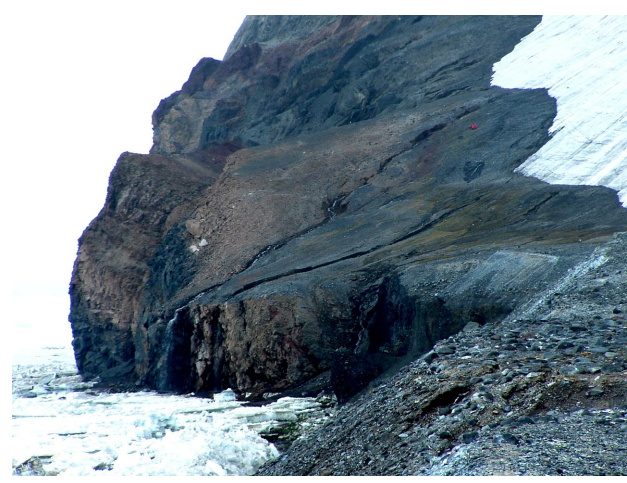

Fig. 1. Sampling sites on Beaufort Island.

\section{Isolation of microfungi}

Fungi were isolated from the soil samples using a modification of the soil plate method (Warcup 1950). Approximately $0.1 \mathrm{~g}$ of soil was placed on the agar surface and distributed using $1 \mathrm{ml}$ of sterile distilled water and rotating the plate. Five replicates were plated on isolation media obtained from OXOID (Potato dextrose agar - PDA) and incubated at $4^{\circ} \mathrm{C}$ or $25^{\circ} \mathrm{C}$. Isolated fungi were categorized into standard thermal classes psychrophilic fungi only growing at $4{ }^{\circ} \mathrm{C}$, psychrotolerant growing at both $4^{\circ}$ and $25^{\circ} \mathrm{C}$, and mesophilic growing only at possesses the most extensive continuous stand of mosses yet known from the McMurdo Sound region. The field survey was carried out during the austral summer of 2004/05 JS. Twenty-three soil samples from 20 sites were obtained. The upper $10 \mathrm{~cm}$ of soil were collected using a sterile spatula, placed in sterile polyethylene bags (Whirl-Pack), mixed thoroughly and frozen by reducing temperature over $48 \mathrm{~h}$ period from $1^{\circ}$ to $-20^{\circ} \mathrm{C}$.

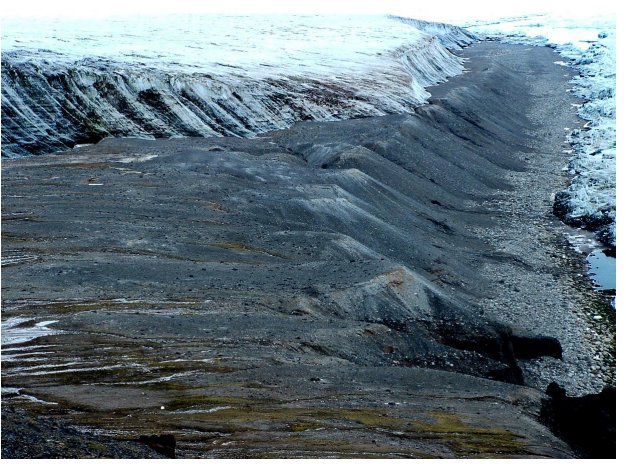

$25^{\circ} \mathrm{C}$. PDA was chosen as the growth media for its ability to encourage growth of many genera of fungi. All plates were examined daily to determine numbers of colonies and to avoid overgrowth of one fungal colony by another. Fungal isolates were sub-cultured for identification. Filamentous fungi were identified to species wherever possible, coupled with the aid of DNA sequencing techniques. Percentage of occurrence of fungi was determined by dividing the frequency of occurrence by the total number of replicates. 


\section{DNA extraction}

DNA was extracted using a modification of the method of Jin et al. (2004). Briefly, homogenized mycelia were incubated in DNA extraction buffer $(100 \mathrm{mM}$ Tris- $\mathrm{HCl}, 50 \mathrm{mM}$ EDTA, 500mM NaCl, $10 \mathrm{mM}$ â-mecaptoethanol [pH8.0], Proteinase-K $(50 \mu \mathrm{g} / \mathrm{mL})$ and SDS $(200 \mathrm{~g} / \mathrm{L}$ [pH 7.2]) at $65^{\circ} \mathrm{C}$ for $2 \mathrm{hrs}$, then cooled on ice before $5 \mathrm{M}$ potassium acetate was added. The mixture was kept on ice for another $20 \mathrm{~min}$ and then centrifuged at
$20,800 \mathrm{~g}$ for $10 \mathrm{~min}$. The supernatant was recovered and purified twice with phenol: chloroform:isoamyl alcohol (PCIA) [25: 24:1]. The genomic DNA was precipitated with ice-cold absolute ethanol, then washed in $70 \%$ ethanol and resuspended in Tris-EDTA buffer [pH 8.0]. The genomic DNA was treated with RNase A $(5 \mathrm{mg} /$ $\mathrm{mL})$ at $65^{\circ} \mathrm{C}$ for $1 \mathrm{~h}$ and stored at $-20^{\circ} \mathrm{C}$. The genomic DNA was visualized on $1.0 \%(\mathrm{w} / \mathrm{v})$ TBE agarose gel.

\section{PCR, cloning and DNA sequencing}

PCR amplification was performed in $15 \mu \mathrm{L}$ reactions that contained $0.2 \mu \mathrm{M}$ forward and reverse primers (combination of ITS5, ITS2, ITS86 and ITS4 primers (White et al. 1990, Turenne et al. 1999) for the ITS1-5.8S-ITS2 region; EF4 and EF3 primers (Smith et al. 1999) for the 18S rDNA region), $0.2 \mathrm{mM}$ dNTPs, 1x DyNAzyme ${ }^{\mathrm{TM}}$ II DNA Polymerase Reaction buffer, 2 U DyNAzyme ${ }^{\mathrm{TM}}$ II DNA Polymerase Recombinant Enzyme (Finnzymes; Finland), 5\% DMSO and 10 ng of genomic DNA. PCR for the ITS15.8S-ITS2 region was performed in a BioRad MyCycler ${ }^{\mathrm{TM}}$ Thermal Cycler (BioRad Laboratories Inc.; USA) with an initial denaturation of $94^{\circ} \mathrm{C}$ for $5 \mathrm{~min}$ followed by 35 cycles of $94^{\circ} \mathrm{C}$ for $30 \mathrm{~s}$, $45-50^{\circ} \mathrm{C}$ for $40 \mathrm{~s}$, and $72^{\circ} \mathrm{C}$ extension for 1 min, with final extension at $72^{\circ} \mathrm{C}$ for 15 min. PCR for the $18 \mathrm{~S}$ rDNA region followed a similar programme but used $54^{\circ} \mathrm{C}$ as the annealing temperature. PCR products were visualized on $2 \%(\mathrm{w} / \mathrm{v})$ TBE agarose gel. The PCR products were purified from the agarose gels using PureLink $^{\mathrm{TM}}$ Quick Gel Extraction Kit (Invitrogen; USA) and then cloned into pGEM $^{\mathbb{R}}$-T Easy Vector (Promega; USA). White colonies were randomly selected and the presence of the ITS or 18S rDNA inserts were confirmed by PCR amplification. Colony PCR reaction $(15 \mu \mathrm{L})$ contained $0.2 \mu \mathrm{M}$ M13 forward and reverse primers, $0.2 \mathrm{mM}$ dNTPs, $1 \mathrm{x}$ DyNAzyme $^{\mathrm{TM}}$ II DNA Polymerase Reaction buffer and 2 U DyNAzyme ${ }^{\mathrm{TM}}$ II DNA Polymerase Recombinant Enzyme (Finnzymes; Finland). Colony PCR was performed in a Bio-Rad MyCycler $^{\mathrm{TM}}$ Thermal Cycler (Bio-Rad Laboratories, Inc.; Hercules, USA) with an initial denaturation of $94^{\circ} \mathrm{C}$ for $10 \mathrm{~min}$ followed by 25 cycles of $94^{\circ} \mathrm{C}$ for $30 \mathrm{~s}, 60^{\circ} \mathrm{C}$ for 40 $\mathrm{s}$, and $72^{\circ} \mathrm{C}$ extension for $1-2 \mathrm{~min}$, with final extension at $72^{\circ} \mathrm{C}$ for $15 \mathrm{~min}$. PCR products were visualized on $2 \%(\mathrm{w} / \mathrm{v})$ TBE agarose gel. PCR products from the colony PCR were purified using the AccuPrep ${ }^{\circledR}$ PCR Purification Kit (Bioneer; South Korea). DNA sequencing was outsourced and performed by SolGent Incorporated Sequencing Services (Daejeon; South Korea) using M13 forward and reverse primers. Sequence chromatograms were checked for ambiguity and edited in Chromas 2.33 (Technelysium Pt. Ltd.; Australia), before being submitted to the GenBank database. 


\section{Sequence alignment}

Multiple sequence alignment was performed separately for the ITS and 18S rDNA sequences using Clustal $\mathrm{W}$ in MEGA 5.2 (Tamura et al. 2011), which included also sequences from Basic Local

\section{Phylogenetic analysis}

The best evolutionary model was chosen separately for the ITS and 18S rDNA aligned datasets using jModelTest 2.1.3 (Darriba et al. 2012) based on the corrected Akaike Information Criterion (AICc). Phylogenetic analyses to construct Neighbour Joining (Maximum likelihood distance) and Maximum Parsimony (heuristic search with 10 replicates of random sequence addition; unordered nucleotide changes with accelerated transformation (ACCTRAN); Tree Bisection Reconnection (TBR) algorithm for branch swapping) trees were performed with 1000
Alignment Search Tool (BLAST) comparisons and other fungi reference sequences obtained from GenBank. Alignments were inspected, corrected and trimmed manually to achieve maximum homology.

bootstrap replicates in PAUP $4.0 \mathrm{~b} 10$ (Swofford 2002). Bayesian analyses were computed in MrBayes 3.1.2 (Ronquist et Huelsenbeck 2003) whereby trees with the highest posterior probabilities were sampled by Metropolis-coupled Markov Chain Monte Carlo (MCMCMC) from four chains of 1,000,000 generations at every 100 generations. The initial $25 \%$ of the trees were discarded as "burn-in" to ensure the chains reached stationarity. Only branches with over $70 \%$ bootstrap values or posterior probabilities were considered in all phylogenetic trees.

\section{Results}

\begin{tabular}{|c|l|c|c|c|}
\hline No. & \multicolumn{1}{|c|}{ Species } & $\mathbf{4}^{\circ} \mathbf{C}$ & $\mathbf{2 5}^{\circ} \mathbf{C}$ & $\begin{array}{c}\text { Total frequency } \\
\text { of occurrence (\%) }\end{array}$ \\
\hline 1. & Thelebolus microsporus & 12.5 & - & $\mathbf{1 2 . 5}$ \\
\hline 2. & Geomyces sp. & 2.33 & 8.43 & $\mathbf{1 0 . 7 6}$ \\
\hline 3. & Thelebolus sp. & 11.34 & 0.29 & $\mathbf{1 1 . 6 3}$ \\
\hline 4. & Asco JBI8 & - & 9.59 & $\mathbf{9 . 5 9}$ \\
\hline 5. & Phoma herbarum & 8.43 & 0.87 & $\mathbf{9 . 3 0}$ \\
\hline 6. & JBIsp5 & 2.91 & 4.94 & $\mathbf{7 . 8 5}$ \\
\hline 7. & Thelebolus globosus & 3.49 & - & $\mathbf{3 . 4 9}$ \\
\hline 8. & Asco sp. 5 & 1.74 & - & $\mathbf{1 . 7 4}$ \\
\hline 9. & White yeast & 2.91 & - & $\mathbf{3 . 4 9}$ \\
\hline 10. & Pink yeast & 1.16 & 1.16 & $\mathbf{2 . 4 1}$ \\
\hline
\end{tabular}

Table 1. Fungi isolated from relictual penguin rookery soils, Beaufort Island and their overall frequency of occurrence. 


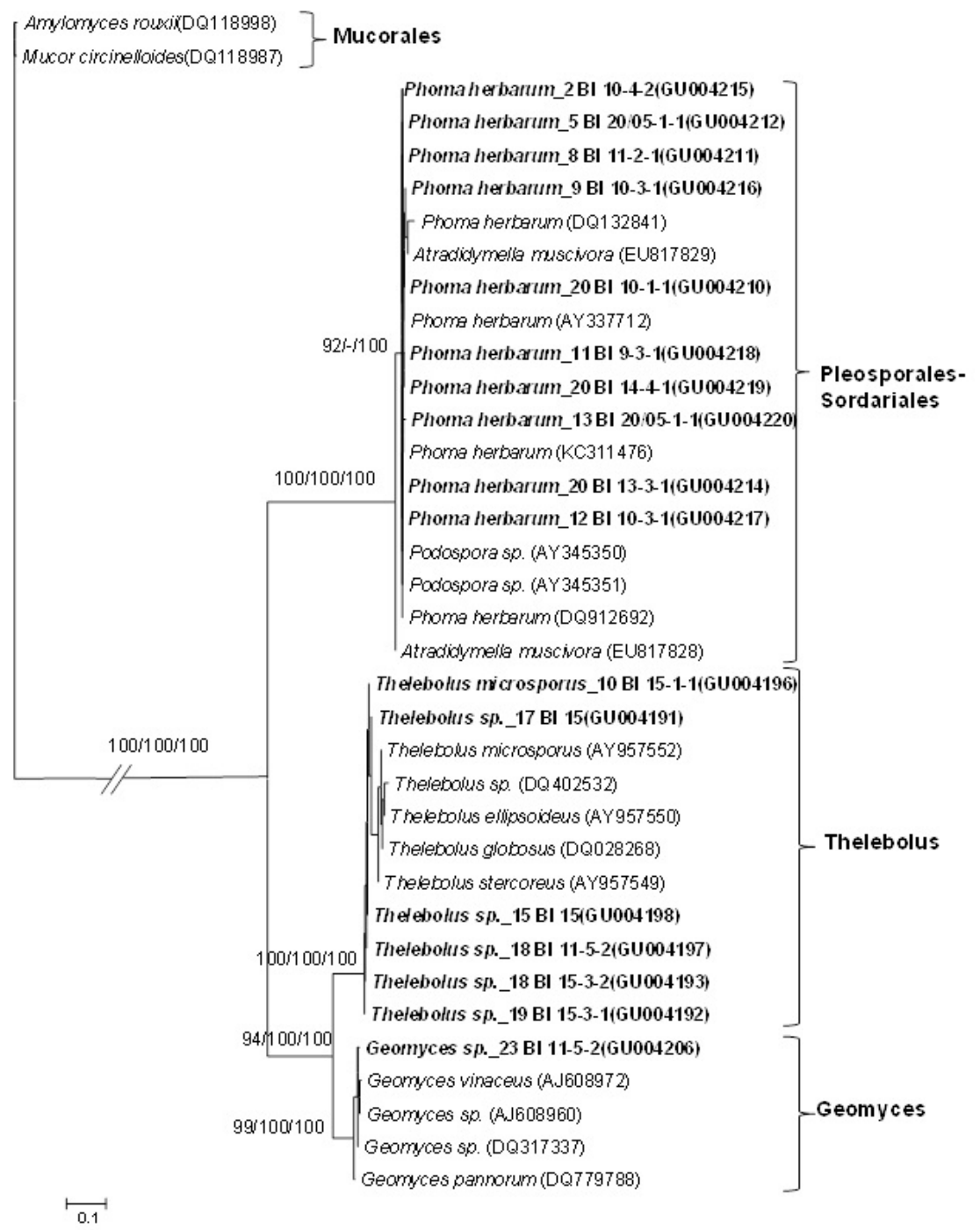

Fig. 2. Neighbour Joining phylogram of fungal isolates from Beaufort Island soil samples (in bold) using ITS1-5.8S-ITS2 sequences (564 bp). Tree is based on maximum likelihood distance (AICc best-fit model selected by jModelTest is $\operatorname{TrN}+\mathrm{G}$ : gamma $=0.8360$; substitution rates $r \mathrm{AC}=1.0000$, $r \mathrm{AG}=3.8962, \quad r \mathrm{AT}=1.0000, \quad r \mathrm{CG}=1.0000, \quad r \mathrm{CT}=5.8151, \quad r \mathrm{GT}=1.0000 ; \quad$ base frequencies $f \mathrm{~A}=0.2591, f \mathrm{C}=0.2248, f \mathrm{G}=0.2214, f \mathrm{~T}=0.2947)$. Bootstrap values for Neighbour Joining, Maximum Parsimony and posterior probability values for Bayesian analysis are shown at the branches, respectively. Sequences from BLAST results and reference sequences were also included and the tree is rooted with Mucorales fungi. GenBank accession numbers of sequences are shown in parentheses. 


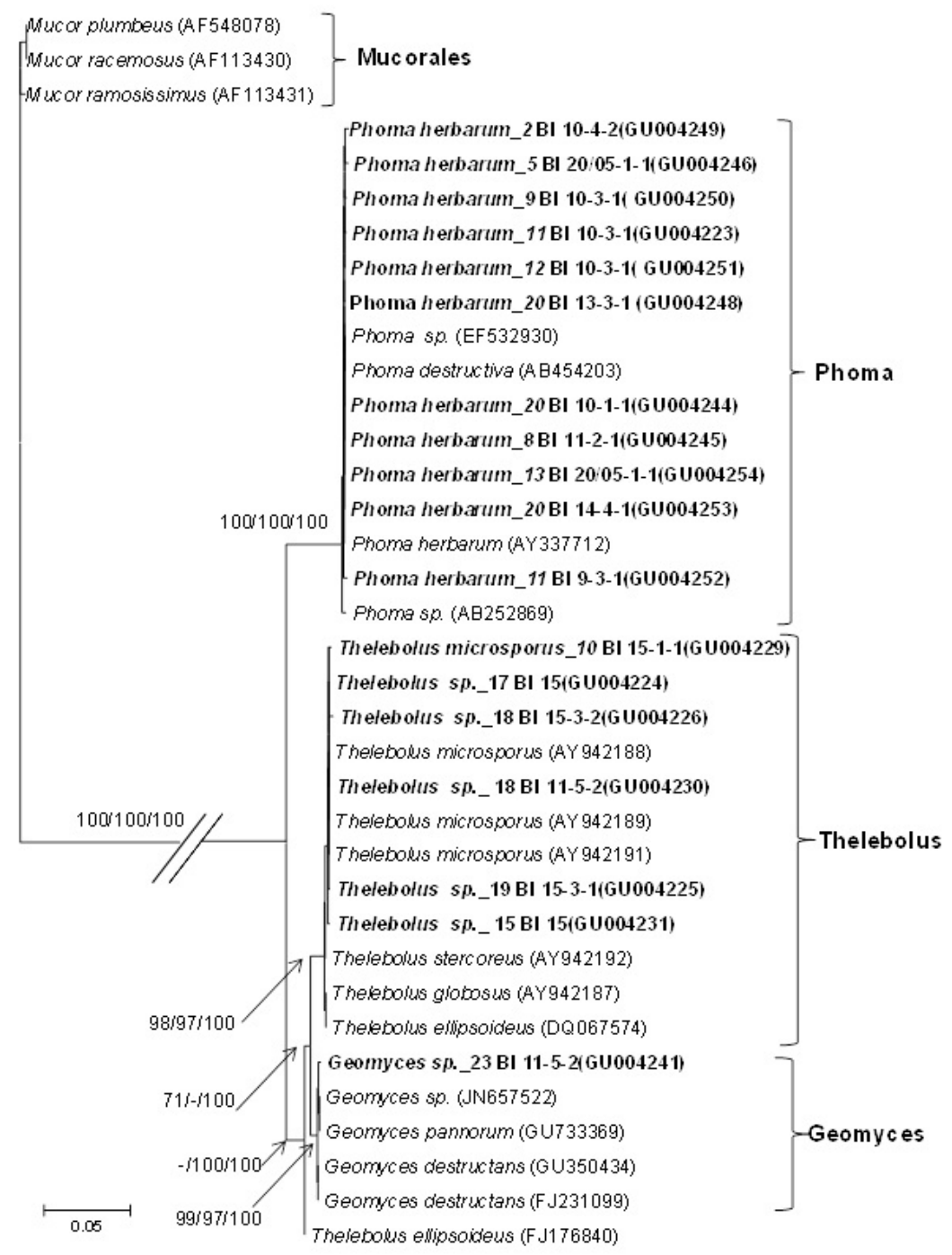

Fig. 3. Neighbour Joining phylogram of fungal isolates from Beaufort Island soil samples (in bold) constructed using 18 rDNA sequences $(1561 \mathrm{bp})$. Tree is based on maximum likelihood distance (AICc best-fit model selected by jModelTest is TIM1+I: rate $=$ equal; $\mathrm{I}=0.6210$, substitution rates $r \mathrm{AC}=1.0000, r \mathrm{AG}=2.7871, r \mathrm{AT}=0.4272, r \mathrm{CG}=0.4272, r \mathrm{CT}=6.6625, r \mathrm{GT}=1.0000$; base frequencies $f \mathrm{~A}=0.2629, f \mathrm{C}=0.2030, f \mathrm{G}=0.2602, f \mathrm{~T}=0.2739$ ). Bootstrap values for Neighbour Joining, Maximum Parsimony and posterior probability values for Bayesian analysis are shown at the branches, respectively. Sequences from BLAST search results and reference sequences are also included and the tree is rooted with Mucorales fungi. GenBank accession numbers of sequences are shown in parentheses. 
Table 1 shows the frequency of occurrence of isolated fungi growing at the different temperatures of $4^{\circ} \mathrm{C}$ and $25^{\circ} \mathrm{C}$. In total, ten taxa were isolated from relictual rookeries. The majority of these were ascomycetes (seven species), with two anamorphic fungi and one yeast. Phylogenetic analysis of the ITS and 18S rDNA sequences confirmed the isolates as Thele-

\section{Discussion}

Azmi et Seppelt (1998) reported only seven taxa isolated from penguin-associated soils from the Windmill Islands, but also noted high occurrence of sterile mycelia and Mortierella sp. In the present study, the mycoflora of Beaufort Island was dominated by ascomycetes. Thelebolus microsporus was found at various sites in the Windmill Islands region (Azmi et Seppelt 1998), but most frequently at sites under seabird influence. Similarly, where sites are strongly influenced by relictual penguin colonies on Beaufort Island, T. microsporus also occurred at a very high percentage.

Anamorphic fungi are known to be able to colonise extreme environments, and are also able to utilise toxic substances that are otherwise lethal to other groups of fungi (Thomas et Hill 1976, Jongmans et al. 1997). As the toxicity reduces, other groups of fungi such as ascomycetes can start to colonise an area, and the presence of hyphomycetes will proportionately reduce. Hyphomycetes are known to survive in xeric environments (Gunde-Cimerman et al. 2003), some can help degrade petroleum (Kirk et Gordon 1988), while others are pathogenic to rotifers and tardigrades in Antarctic lakes (McInnes 2003) or are nematophagous (Gray et al. 1982). The numbers of taxa of psychrophilic and psychrotolerant fungi recorded on Beaufort Island were 9 and 5, respectively. Robinson (2001) highlighted the predominance of psychrotolerance in the myco- bolus microsporus, Thelebolus sp., Phoma herbarum and Geomyces sp. (see Fig. 2, 3). Thelebolus microsporus, Thelebolus sp. and Asco BI8. were the most commonly isolated fungi, with frequencies of occurrence of $>10 \%$ (Table 1). Of the fungi obtained, four taxa grew only at $4^{\circ} \mathrm{C}$, four at both 4 and $25^{\circ} \mathrm{C}$, and one only at $25^{\circ} \mathrm{C}$.

biota of the Arctic and Antarctic noting that, although the most of fungi isolated from the Antarctic are able to grow at around $0^{\circ} \mathrm{C}$, the temperature of substrata in some periods of the year can be much higher than the air temperature (see also Möller et Dreyfuss 1996).

Azmi et Seppelt (1998) observed that fungal diversity was low in guaniferous soil in the centre of active penguin colonies. In the present study, no fungi were isolated from active penguin rookeries where the soils were waterlogged with sea water and fresh penguin guano. This most likely is due to the high ammonia concentration in fresh guano (Legrand et al. 1998, Rankin et Wolff 2000), and also to the presence of acrylic acid, a microbial antagonist that is often detected in ornithogenic soils from active penguin rookeries (Fletcher et al. 1985, Roser et al. 1994).

Geomyces spp. are widely distributed in Antarctica (Fletcher et al. 1985, Kerry 1990a, b, Azmi et Seppelt 1998, Gilichinsky et al. 2005), occurring under varying environmental conditions (Kerry 1990a, b). Although capable of producing cellulase at $1^{\circ} \mathrm{C}$ (Hurst et al. 1983) and psychrotolerant, members of the genus are thought to be poor competitors (Ivarson 1974). Kerry (1990a, b) noted the absence or low frequency of occurrence Geomyces pannorum when other fungal species such as Phoma herbarum were present. In contrast, in the current study, the mycobiota was dominated by Thelebolus spp., Geo- 
myces sp. and Asco JBI8. This suggests that the community observed here shows a clear signal of the founder effect. Although members of the genus Geomyces are no longer categorised as hyphomycetes, they are amongst the best-known examples of primary colonising microfungi (Ivarson 1974).

\section{References}

Alias, S. A., ABDUl WAHAB, A. and OMAR, S. (2005): Occurrence of filamentous microfungi from Windmill Islands. Proceedings of Seminar "Antarctic Research in the University of Malaya", Academy of Sciences Malaysia, pp. 99-103.

Allen, S. E., GrimshaW, H. M. and Holdgate, M. W. (1967): Factors affecting the availability of plant nutrients on an Antarctic island. Journal of Ecology, 55: 381-396.

Atlas, R. M., Di Menna, M. E. and CAmeron, R. E. (1978): Ecological Investigation of yeasts. Mycologia, 61: 748-774.

Azmi, O. R., Seppelt, R. D. (1998): The broad scale distribution of microfungi in the Windmill Islands region, continental Antarctica. Polar Biology, 19: 92-100.

Blanchette, R. A. (2000): A review of microbial deterioration found in archaeological wood from different environments. International Biodeterioration and Biodegradation, 46: 189-204.

Blanchette, R. A., Held, B. W., Jurgens, J. A., McNew, D. L., Harrington, T. C., Duncan, S. M. and FARREL, R. L. (2004): Wood destroying soft-rot fungi in the historic expedition huts of Antarctica. Applied and Environmental Microbiology, 1: 1328-1335.

Cameron, R. E., Conrow, H. P., Gensel, D. R., Lacy, G. H. and Morelli, F. A. (1971): Surface distribution of microorganisms in Antarctic dry-valley soils: a Martian analog. Antarctic Journal, (Sept-Oct 1971): 211-213.

Cheryl, F. M., Seppelt, R. D. (1999): Filamentous fungi of the Windmill Islands, continental Antarctica. Polar Biology, 22: 389-394.

ChOwn, S. L., GASTON, K. J. (2000): Island-hopping invaders hitch a ride with the tourists in South Georgia. Nature, 48: 637.

Darriba, D., Taboada, G.L., Doallo, R. and Posada, D. (2012): jModelTest 2: more models, new heuristics and parallel computing. Nature Methods, 9: 772.

Del Frate, G., Caretta, G. (1990): Fungi isolated from Antarctic material. Polar Biology, 11: 1-7.

DENNIS, R.W.G. (1968): Fungi from South Georgia. Kew Bulletin, 22: 445-448.

EmSlie, S.D., CoATs, L. and Licht, K. (2007): A 45,000 year record of Adélie penguins and climate change in the Ross Sea, Antarctica. Geology, 35: 61-64.

Finotti, E., Moretto, D., Marsella, R. and Mercantini, R. (1993): Temperature effects and fatty acid patterns in Geomyces species isolated from Antarctic soil. Polar Biology, 13: 127130.

Fletcher, L. D., Kerry, E. J. and Weste, G. M. (1985): Microfungi of MacRobertson and Enderby Lands, Antarctica. Polar Biology, 4: 81-88.

Frenot, Y., Chown S. L., Whinam, J., Selkirk P. M., Convey, P., Skotnicki, M. and Bergstrom D. M. (2005): Biological invasions in the Antarctic: extent, impacts and implications. Biological Reviews, 80: 45-72.

FriedMANN, E. I. (1982): Endolithic microorganisms in the Antarctic cold desert. Science, 215: 1045-1053.

Friedmann, E. I., McKay, C. P. and Nienow, J. A. (1985): The cryptoendolithic microbial environment in the Ross Desert of Antarctica. Satellite-transmitted continuous nanoclimate data, 1984-1986. Polar Biology, 7: 283-287.

Gilichinsky, D., Rivkina, E., Bakermans, C., Shcherbakova, V., Petrovskaya, L., Ozerskaya, S., Ivanushina, N., Kochiona, G., Laurinavichuis, K., Pecheritsina, S., FAtTAKhova, R. and TiedjC, J. M. (2005): Biodiversity of cryopegs in permafrost. FEMS Microbiology Ecology, 53: 117-128. 
Gray, N. F., Wyborn, C. H. E. and Smith, R. I. L. (1982): Nematophagus fungi from the maritime Antarctic. Oikos, 38: 194-201.

Gunde-Cimerman, N., Sonjak, S., Zalar, P., Frisvad, J. C., Diderichsen, B. and Plementaš, A. (2003): Extremophilic fungi in arctic ice: a relationship between adaptation to low temperature and water activity. Physics and Chemistry of the Earth, 28: 1273-1278.

Held, B. W., Jurgens, J. A., Arenz, B. E., Duncan, S. M., Farrel, R. L. and Blanchette, R. A. (2005): Environmental factors influencing microbial growth inside the historic expedition huts of Ross Island, Antarctica. International Bioterioration and Biodegradation, 55: 45-53.

Hughes, K. A., Lawley, B. and Newsham, K. K. (2003): Solar UV-B radiation inhibits the growth of Antarctic terrestrial fungi. Applied and Environmental Microbiology, 69: 1488-1491.

Hurst, J. L., Pugh, G. J. F. and Walton, D. W. H. (1983): Fungal succession and substrate utilization on leaves of three South Georgia phanerograms. British Antarctic Survey Bulettin, 56: 89-100.

IVARSON, K. C. (1974): Comparative survival and decomposing ability of four fungi isolated from leaf litter at low temperatures. Canadian Journal of Soil Science, 54: 245-260.

JIN, J., LEE, Y. K. and WiCKES, B. L. (2004): Simple chemical extraction method for DNA isolation from Aspergillus fumigatus and other Aspergillus species. Journal of Clinical Microbiology, 42: 4293-4296.

Jongmans, A. G., van Breemen, N., Lundström, U., van Hees, P. A. W., Finlay, R. D., Srinivasan, M., Unestam, T., Giesler, R., Melkerud, P.-A. and Olsson, M. (2001): Rockeating fungi (scientific correspondence). Nature, 389: 682-683.

KERRY, E. (1990a): Microorganisms colonizing plants and soil subjected to different degree of human activity, including petroleum contamination in the Vestfold Hills and MacRobertson Land, Antarctica. Polar Biology, 10: 423-430.

KERRY, E. (1990b): Effects of temperature on growth rates of fungi from subantarctic Macquarie Island and Casey, Antarctica. Polar Biology, 10: 293-299.

KIRK, P. W., GORDON, A. S. (1988): Hydrocarbon degradation by filamentous marine higher fungi. Mycologia, 80: 776-782.

Krishnan, A., Alias, S. A., Wong, C. M. V. L., PAng, K. L. and Convey, P. (2011): Extracellular hydrolase enzyme production by soil fungi from King George Island, Antarctica. Polar Biology, 34: 1535-1542.

Legand, M., Ducroz, F., Wagenbach, D., Mulvaney, R. and Hall, J. S. (1998): Ammonium in coastal Antarctic aerosol and snow: role of the polar ocean and penguin emissions. Journal of Geophysical Research, 103: 11043-11056.

Marshall, W. A. (1997): Seasonality of Antarctic fungal spores. Applied and Environmental Microbiology, 63: 2240-2245.

MARTIN, A. (1988): Microbial flora of some soils of Mawson Base and the Vestfold Hills, Antarctica. Polar Biology, 8: 421-427.

MCINNES, S. (2003): A predatory fungus (Hyphomycetes: Lecophagus) attacking Rotifera and Tardigrada in maritime Antarctic lakes. Polar Biology, 26: 79-8.

Möller, C., Gams, W. (1993): Two new hyphomycetes isolated from Antarctic lichens. Mycotaxon, 48: 441-450.

MÖLlER, C., DREYfuss, M. M. (1996): Microfungi from Antarctic lichens, mosses and vascular plants. Mycologia, 88: 922-933.

Myrcha, A., Pietr, S. J. and Tatur, A. (1985): The role of pygoscelid penguin rookeries in nutrient cycles at Admiralty Bay, King George Island. In: W. R. Siegfried, P. R. Condy, R. M. Laws (eds.): Antarctic nutrient cycle and food webs. Springer-Verlag, Berlin, Heidelberg, New York, pp. 156-162.

Myrcha, A., TAtur, A. (1991): Ecological role of current and abandoned penguin rookeries in the land environment of the Maritime Antarctic. Polish Polar Research, 12: 3-24.

ONOFRI, S., TOSI, S. (1992): Arthrobotrys ferox sp. nov., a springtail-capturing Hyphomycete from continental Antarctica. Mycotaxon, 44: 445-451. 
Panikov, N. S., Flanagan, P. W., Oechel, W. C., Mastepanov, M. A. and Christensen, T.R. (2006): Microbial activity in soils frozen to below $-39^{\circ} \mathrm{C}$. Soil Biology and Biochemistry, 38: 785-794.

PARK, J-H., DAY, T. A., STRAuSs, S. and RuHLAND, C. T. (2007): Biogeochemical pools and fluxes of carbon and nitrogen in a maritime tundra near penguin colonies along the Antarctic Peninsula. Polar Biology, 30: 199-207.

Pugh, G. J. F., Allsopp., D. (1982): Microfungi on Signy Island, South Orkney Islands. British Antarctic Survey Bulletin, 57: 55-67.

Rankin, A. W., WolfF, E. W. (2000): Ammonium and potassium in snow around an emperor penguin colony. Antarctic Science, 12: 154-159.

Robinson, C. H. (2001): Cold adaptation in Arctic and Antarctic fungi. New Phytologist, 151: 341-353.

RonQuist, F., HuELSENBECK, J. P. (2003): MRBAYES 3: Bayesian phylogenetic inference under mixed models. Bioinformatics, 19: 1572-1574.

Roser, D. J., Seppelt, R. D. and Nordstorm, O. (1994): Soluble carbohydrate and organic content of soils and associated microbiota from the Windmill Islands, Budd Coast, Antarctica. Antarctic Science, 6: 53-59.

Selbmann, L., de Hoog, G. S., Mazzaglia, A., Friedmann, E. I. and Onofri, S. (2005): Fungi at the edge of life: Cryptoendolithic black fungi from Antarctic desert. Studies in Mycology, 51: 132.

Selmi, S., Boulinier, T. (2001): Ecological biogeography of southern ocean islands: the importance of considering spatial issues. The American Naturalist, 158: 426-437.

Seppelt, R. D., Green, T. G. A. and SkotNicki, M. (1999): Notes on the flora, vertebrate fauna and biological significance of Beaufort Island, Ross Sea, Antarctica. Polarforschung, 66: 53-59.

SмITH, R. I. L. (1985): Nutrient cycling in relation to biological productivity in Antarctic and subAntarctic terrestrial and freshwater ecosystems. In: W. R. Siegfried, P. R. Condy, R. M. Laws (eds.): Antarctic nutrient cycles and food webs. Springer-Verlag, Berlin, Heidelberg, New York, pp. 138-155.

Smith, R. I. L. (1994): Species diversity and resource relationships of South Georgian fungi. Antarctic Science, 6: 45-52.

SMYKLA, J., Wolek, J. and BARCiKowski, A. (2007). Zonation of vegetation related to penguin rookeries on King George Island, Maritime Antarctic. Arctic, Antarctic and Alpine Research, 39: 143-151.

Stonehouse, B. (1966): Emperor penguin colony at Beaufort Island, Ross Sea, Antarctica. Nature, 210: 925-926.

Sugiyama, J., Sugiyama, Y., IIzuka, H. and ToriI, T. (1967): Report of the Japanese Summer Parties in Dry Valleys, Victoria Land, 1963-1965. IV. Mycological Studies of the Antarctic Fungi. Part. 2. Mycoflora of Lake Vanda, an ice-free lake. The Antarctic Record, Tokyo, 28: 23-32.

SwOFFord, D. L. (2002): PAUP*. Phylogenetic Analysis Using Parsimony (*and Other Methods). Sinauer Associates, Sunderland, Massachusetts.

Tamura, K., Peterson, D., Peterson, N., Stecher, G., Nei, M. and Kumar, S. (2011): MEGA5: Molecular Evolutionary Genetics Analysis using Maximum Likelihood, Evolutionary Distance, and Maximum Parsimony Methods. Molecular Biology and Evolution, 28: 2731-2739.

Tatur, A. (1989): Ornithogenic soils of Maritime Antarctic. Polish Polar Research, 104: 481-532.

TATUR, A. (2002): Ornithogenic ecosystems in Maritime Antarctic - Formation, development and disintegration. In: L. Beyer, M. Bölter (eds.): Geoecology of Antarctic ice-free Coastal Landscapes. Ecological Studies 156, Springer, Berlin, pp. 161-184.

TAtur, A., Myrcha, A. (1989): Soils and vegetation in abandoned penguin rookeries (maritime Antarctic). Polar Biology, 2: 181-189.

Tatur, A., Myrcha, A. and Niegodzisz, J. (1997): Formation of abandoned penguin rookery ecosystems in maritime Antarctic. Polar Biology, 17: 405-417.

Thomas, A. R., Hill, E. C. (1976): Aspergillus fumigatus and supersonic aviation. I. Growth of A. fumigatus. International Biodeterioration Bulletin, 12: 87-94. 
TUBAKI, K. (1961): On some fungi isolated from the Antarctic materials. Biological results of the Japanese Antarctic Research Expedition (14). Special publications from the Seto Marine Biological Laboratory. $9 \mathrm{p}$.

VidAL, E., Jouventin, P. and Frenot, Y. (2003): Contribution of alien and indigenous species to plant-community assemblages near penguin rookeries at Crozet archipelago. Polar Biology, 26: 432-437.

WARCUP, J. H. (1950): The soil plate method for isolation of fungi from soil. Nature, 166: 117118.

Weinstein, R. N., Palm, M. E., Johnstone, K. and Wynn-Williams, D. D. (1997): Ecological and physiological characterization of Humicola marvinii, a new psychrophilic fungus from fellfield soils in the maritime Antarctic. Mycologia, 89: 706-711.

WiCKLOW, D. T. (1968): Aspergillus fumigatus Fresenius isolated from ornithogenic soil collected at Hallet Station, Antarctica. Canadian Journal of Microbiology, 14: 717-719.

Wodehouse, E. B., PARKer, B. C. (1981): Atmospheric ammonia nitrogen, a potential source of nitrogen eutrophication of freshwater Antarctic ecosystems. Antarctic Research Series, 30: 155-167.

Woenler, E. J. (1993): The distribution and abundance of Antarctic and Aubantarctic penguins. SCAR, Cambridge, England. pp. iv +76 .

Woenler, E. J., Croxall, J. P. (1996): The status and trends of Antarctic and Subantarctic seabirds. SC-CAMLR-XV/BG/29, pp. 46.

ZmudczyŃska, K., OlejnicZAK, I., ZWOlicki, A., Iliszko, L., Convey, P. and Stempniewicz, L. (2012): Influence of allochtonous nutrients delivered by colonial seabirds on soil collembolan communities on Spitsbergen. Polar Biology, 35: 1233-1245. 